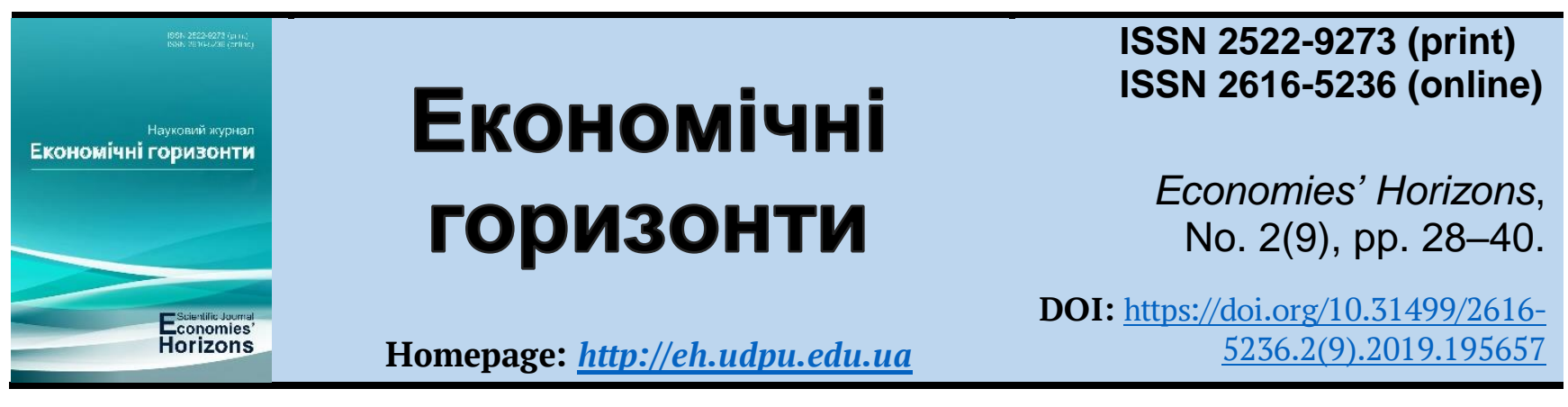

UDC 331.442:616-051](73)

\title{
Professional burnout of family physicians: experience of the research and problem-solving in the USA
}

\author{
Olexandr P. Krupskyi ${ }^{1}$, Cand. Psych. Sc., Associate Professor \\ Olena V. Hromtseva ${ }^{2}$
}

Received: 17 April 2019 Accepted: 24 May 2019
Krupskyi, O. P. and Hromtseva, O. V. (2019), "Professional burnout of family physicians: experience of the research and problem-solving in the USA", Economies' Horizons, no. 2(9), pp. 28-40, doi: https://doi.org/10.31499/2616-5236.2(9).2019.195657.

Abstract. The purpose of the research. The main purpose of the study is to find out the experience of researching and solving the problem of professional burnout for physicians including family ones in the United States, by analyzing recent surveys and scientific papers of American and European scientists. Methodology. While working on the article, general scientific theoretical methods were used to accomplish the tasks and achieve the purpose of the research. The methodological basis of the research was the structural-functional method, which allowed considering the phenomenon of professional burnout as a whole with separate elements and their dependencies. Using a historical method, a brief overview of the research development by US scientists on the problem of professional burnout of physicians with a focus on key events that occurred at each of the stages highlighted in the scientific papers. A comparative method was used to compare the results of surveys of different years and topics, data presented in the proceedings of the scientists, and research approaches. Methods of systematization and generalization were used to formulate the paper's conclusions, in particular, to highlight the essential features of the American research experience and practical problem solution of professional burnout of physicians. Results. It has been found that the professional burnout of physicians has been a matter of concern for the government, professional medical associations, and the general public for physicians of various US specialties for a long time. Although burnout affects physicians of all disciplines, it has been discovered that, among family physicians, this phenomenon exceeds the average level, especially compared to the general economically active population of the United States. Two approaches to identifying and reducing the risk of occupational burnout in the United States have been identified and characterized: the first approach covers measures aimed directly at a physician, that is, a specific individual, and the second, involves measures aimed at an organization, that is, a medical institution. It has been found that American scientists have concluded that organizational measures are more effective, but the first approach should be applied as a first step in overcoming professional burnout. Practical meaning. The results of the research are applicable for further scientific exploration and practical problem solution of profes-

\footnotetext{
${ }^{1}$ Oles Honchar Dnipro National University; Associate Professor at the Department of Management and Tourism Business; ORCID ID: http://orcid.org/0000-0002-1086-9274; e-mail: krupskyy71@gmail.com.

${ }^{2}$ Oles Honchar Dnipro National University; postgraduate student in the Department of Management and Tourism Business; ORCID ID: http://orcid.org/0000-0001-8353-4638; e-mail: fufushka@meta.ua; Scientific Adviser - O. P. Krupskyi, Cand. Psych. Sc., Associate Professor.
} 
sional burnout of physicians, including family ones, in Ukraine. Prospects for further research. Methodology of surveys of physicians of various specialties on burnout, depression and professional satisfaction. Factors of professional burnout for family physicians in Ukraine.

Keywords: health care management, stress at work, stress management, organizational behavior, professional burnout, satisfaction of physicians.

JEL Classification: I 12, I 19, J 44.

Number of references: 45; number of tables: 0; number of figures: 1; number of formulas: $\mathbf{0 .}$

\title{
Професійне вигоряння сімейних лікарів: досвід дослідження та вирішення проблеми в США
}

\author{
Олександр Петрович Крупський ${ }^{1}$, к. психол. н., доцент \\ Олена Віталіївна Громцева ${ }^{2}$
}

Стаття надійшла: 17.04.2019 Стаття прийнята: 24.05.2019
Krupskyi O. P., Hromtseva O. V. Professional burnout of family physicians: experience of the research and problem-solving in the USA. Економічні горизонти. 2019. № 2(9). C. 28-40. DOI: 10.31499/2616-5236.2(9).2019.195657.

Анотація. Мета дослідження. Головна мета статті полягає вивченні досвіду дослідження та вирішення проблеми професійного вигоряння лікарів, зокрема сімейних, в США, на основі аналізу останніх за часом опитувань та наукових праць американських і європейських учених. Методологія. Під час роботи над статтею були використані загальнонаукові теоретичні методи за допомогою яких були виконані завдання і досягнуто мету дослідження. Методологічною основою дослідження став структурно-функціональний метод, який дозволив розглянути феномен професійного вигоряння, як єдине ціле з окремими елементами та залежностями між ними. За допомогою історичного методу зроблений стислий огляд розвитку досліджень ученими США проблеми професійного вигоряння лікарів з акцентом на ключові події, які сталися на кожному з виділених в наукових працях етапів. Для порівняння результатів опитувань різних років та тематик, даних, які наводяться в працях учених, та дослідницьких підходів використовувався компаративний метод. Методи систематизації та узагальнення використовувалися для формулювання висновків статті, зокрема з метою виділення суттєвих ознак американського досвіду дослідження та практичного вирішення проблеми професійного вигоряння лікарів. Результати. З'ясовано, що професійне вигоряння лікарів $є$ предметом стурбованості уряду, професійних медичних асоціацій та широкого загалу лікарів різних спеціальностей США вже протягом тривалого часу. Встановлено, що хоча вигоряння впливає на лікарів усіх спеціальностей, серед сімейних лікарів це явище перевищує середній рівень, особливо порівняно із загальним економічно активним населенням США. Виявлено та охарактеризовано два підходи до визначення та зменшення ризик професійного вигоряння лікарів в США: перший підхід охоплює заходи, спрямовані безпосередньо на лікаря, тобто на конкретного індивіда, а другий - передбачає заходи, спрямовані на організацію, тобто на медичний заклад. Американські учені дійшли висновку, що заходи, спрямовані на організацію $\epsilon$ більш ефективними, однак перший підхід слід застосовувати як перший крок у подоланні

\footnotetext{
1 Дніпровський національний університет імені Олеся Гончара; доцент кафедри менеджменту та туристичного бізнесу; ідентифікатор ORCID: http://orcid.org/0000-0002-1086-9274; e-mail: krupskyy71@gmail.com.

2 Дніпровський національний університет імені Олеся Гончара; аспірант кафедри менеджменту та туристичного бізнесу; ідентифікатор ORCID: http://orcid.org/0000-0001-8353-4638; e-mail: fufushka@meta.иа; науковий керівник - О. П. Крупський, к. психол. н., доцент.
} 
професійного вигоряння. 3'ясовано, що американські учені дійшли висновку, що заходи, спрямовані на організацію є більш ефективними, однак перший підхід слід застосовувати як перший крок у подоланні професійного вигоряння. Практичне значення. Результати дослідження можуть бути використані для подальших наукових розвідок та практичного вирішення проблеми професійного вигоряння лікарів, зокрема сімейних, в Україні. Перспективи подальших досліджень. Методологія проведення опитувань лікарів різних спеціальностей стосовно вигоряння, депресії та професійного задоволення. Чинники професійного вигоряння сімейних лікарів в Україні.

Ключові слова: управління в системі охорони здоров'я, стрес на роботі, управління стресом, організаційна поведінка, професійне вигоряння, задоволення лікарів роботою.

Кількість джерел: 45; кількість таблиць: 0; кількість рисунків: 1; кількість формул: 0.

\section{Introduction.}

There are important changes in healthcare around the world. The national health systems' agenda raises issues of the proper administration, the development of an appropriate regulatory environment, the introduction of new digital technologies in health care management and clinical practice, the health services effectiveness and efficiency, as well as improvement of organizational culture and behavior (Health at a Glance, 2019; Tools and methodologies, 2019). However, all these changes are leading to more and more demands on physicians and, as a result, a rapid increase in the number of occupational burnout, depression, stress, job dissatisfaction, frustration in the chosen profession and even suicide among physicians (Wible, 2018).

Medical practice in the US is also at a turning point. With the shift to a pay model based on the effectiveness of health care delivery and the transformation of the health care delivery system in general, health care providers are gaining crisis momentum (Martin, 2016). More than half of American physicians have lost their pleasure in medical practice, are constantly stressed at work, overworked, and increasingly feel professionally "burned out". This development is highly undesirable as it inevitably entails a decline in the quality of health care delivery, inefficient use of resources, an increase in the incidence of medical errors and even a shortage of physicians in certain specialties (Martin, 2016; Kuzmanovich, 2016; Liu, 2016).
The relevance and importance of studying the US experience in research and practical problem solution of the physicians' professional burnout is that it is the American scientists who possess the basic scientific works on the problem of professional burnout, including physicians who have become classic, developed and continue to improve this method. phenomena that have already proven effective and, finally, powerful medical associations have been established in the country, such as the Association of American Medics (AAM) and the American Academy of Family Physicians (AAFP), which promotes the integration of research results into practice. We are confident that in Ukraine, with large-scale medical reform, this research results will be in demand and will inevitably have a practical implementation.

\section{Literature review.}

The issue of professional burnout for physicians is very topical in medical institutions practically all over the world, so a lot of scientific papers, analytical materials prepared by the results of special surveys and expert opinions are devoted to the study of this problem. For instance, the paper of the British researchers authors team of M. Panagioti, E. Panagopoulou, P. Bower, G. Lewith, E. Kontopantelis, C. Chew-Graham, S. Dawson, H. van Marwijk, K. Geraghty and A. Esmail (2017), who have set themselves the purpose of evaluating effectiveness of interventions to reduce the professional burnout of physicians, depending on the subject of 
their referral: directly to the physician or directly to the organization, that is, the medical facility. Based on the results obtained, the scientists concluded that the effectiveness of the activities directly aimed at the organization was more effective.

C. Peckham has dedicated her scientific exploration to the results of a 2018 survey of US physicians on issues of occupational burnout and depression (Peckham, 2018). The author highlighted the key findings of the survey, including the specialties most vulnerable to burnout and the key factors behind this phenomenon, as well as the methods used by physicians to alleviate the symptoms of burnout and depression, and commented on them for the national health care system in general.

The survey analysis is also covered by analytical material from the Advisory Board Company (Advisory Board Company, 2017), which specializes in the United States in the study and dissemination of good practices in healthcare, consulting and new technologies. The same company has proposed four key strategies for reducing burnout for physicians (strategies) focused on changes in healthcare settings and aimed at healthcare leaders. The results of another, somewhat broader, 2019 study on burnout, depression, and suicide among American physicians are analyzed in L. Kane's (2019) paper. The author made the important conclusion that the vast majority of physicians do not seek help in case of burnout or depression. The team of scientists including T. D. Shanafelt, O. Hasan, L. N. Dyrbye, C. Sinsky, D. Satele, J. Sloan, C. P. West, C. M. Balch, G. Bechamps and others (Shanafelt et al., 2016; Shanafelt et al., 2010; Shanafelt et al., 2015) explores the relationship between occupational burnout and medication errors, finding the right balance between physicians' work and personal lives, identifying key burnout factors. Carefully analyzing the results of the surveys, scientists have concluded that family physicians suffer from significantly higher degrees of burnout than physicians in most other specialties.
There are the researches that highlight the presence of burnout with:

- the safety culture inherent in a particular health care facility (Nahrgang, Morgeson and Hofmann, 2011; Montgomery, et al., 2013; Hromtseva and Krupskyi, 2015);

- stress (McManus, Winder and Gordon, 2002; Maslach and Leiter, 2016);

- the professional behavior of medical staff (Chan et al., 2015; Webb et al., 2016);

- satisfaction with the results of their work (Weng et al., 2011; Myhren, Ekeberg and Stokland, 2013).

In general, the range of scientific publications and publications on the issue of professional burnout for physicians, including family physicians, is surprisingly wide in the United States. The problem is addressed comprehensively, using an interdisciplinary approach and state-of-the-art research methods. This paper claims to look at the US experience of theoretical understanding and practical solutions to the problem of professional burnout of physicians, including family ones, and consideration of particular approaches that we believe are of most interest.

\section{Methods.}

While working on the paper, general scientific theoretical methods were used to accomplish the tasks and achieve the purpose of this research. The methodological basis of the research was the structural-functional method, which allowed considering the phenomenon of professional burnout as a whole with separate elements and their dependencies. Using a historical method, a brief overview of the research development by US scientists on the problem of professional burnout of physicians with a focus on key events that occurred at each of the stages highlighted in the scientific papers. A comparative method was used to compare the results of surveys of different years and topics, data presented in the scientists' proceedings, and research approaches. Methods of systematization and generalization were used to formulate the conclusions of the paper, in particular, to highlight the essential 
features of the American experience of research and practical solution to the problem of professional burnout of physicians.

\section{Research objectives.}

The purpose of the research is to clarify the experience of the research and address the problem of professional burnout of physicians, including family ones, in the US, based on the analysis of recent surveys and scientific papers of American and European scientists.

\section{Results and discussions.}

The first scientific papers on burnout at work appeared in the United States in the mid1970s. They were informative and intended to formulate the phenomenon of burnout as such (Freudenberger, 1974; Maslach, 1976). The main contribution of these papers was to name the phenomenon, to describe the key problem, and to show that it is not something rare and unusual. In their research, scientists have relied on the experience of people working in social security and public health - professions that aim to provide assistance and services to people who need them, and can, therefore, be characterized by emotional and interpersonal stress factors (Maslach, Schaufeli and Leiter, 2001, pp. 399-400).

In the 1980s, the burnout work shifted to more systematic empirical studies that were quantitative in nature, based on questionnaires and survey methodologies, and already focused on the research of larger target populations. Particular attention has been paid to the evaluation of burnout, for which several different methods have been developed (Maslach, Jackson, 1981). The transition to empiricism was accompanied by a theoretical and methodological contribution from production-organizational psychology. Burnout was seen as a form of job stress that was related to concepts such as job satisfaction, organizational commitment, and staff turnover (Maslach, Schaufeli and Leiter, 2001, p. 401).

In the 1990s, empirical research continued, but in several new directions: firstly, the concept of burnout extended to other professional fields (e.g., public administration, computer technology, military service, management); secondly, burnout studies were underpinned by more sophisticated methodology, improved statistical tools, and the use of structural models built on the relationships between organizational factors and the three burnout components; thirdly, several longitudinal studies have begun to evaluate the relationship between the work environment at one point in time and the thoughts and feelings of the individual at a later time. All this allowed scientists to investigate the contribution to the burnout process of many potential impacts and consequences simultaneously, to evaluate the effectiveness of certain measures designed to reduce burnout, and to conclude that burnout is the result of the interaction of the individual with the workplace (Maslach, Schaufeli, Leiter, 2001, p. 401).

In the seminal work of American psychologists C. Maslach, W. Schaufeli, and M. Leiter, burnout at work, which has become a classic today, is defined as "a psychological syndrome that arises in response to chronic interpersonal stressors at work". The authors consider the three key aspects of this response to be "overwhelming exhaustion, a sense of cynicism and distancing from work, as well as a sense of inefficiency and lack of success" (Maslach, Schaufeli and Leiter, 2001, p. 399).

Usually, burnout in the United States is measured using a standard tool called the Maslach Burnout Inventory (MBI), a 22-item questionnaire that has 3 additional inventories to assess 3 areas of burnout: emotional exhaustion, impersonation, and lack of personal success awareness. Physicians who have a high score for medical professionals or on an inventory of impersonality and/or on an inventory of emotional exhaustion are considered to have at least one manifestation of professional burnout. Depression symptoms are identified using the Primary Medical Degrees (PRIME MD), which is a standardized and validated assessment tool for depression screening (Shanafelt et al., 2010, p. 996).

According to the 2019 National Burnout 
and Depression Report by Medscape, an English-language web resource for physicians and other healthcare professionals in the United States, over $40 \%$ of physicians, including $50 \%$ of women physicians, have had a professional burnout, although physicians in some specialties suffer more from it than others. The report was based on an online survey of 15,069 physicians (62\% male and $32 \%$ female) of 29 specialties on a variety of topics, including occupational burnout, depression, and job satisfaction (Kane, L., 2019; Physician burnout in 2019, 2019).

Of all the physicians surveyed, $44 \%$ reported experiencing burnout. According to the report, burnout degrees vary by gender: $50 \%$ of female respondents and 39\% reported male burnout. Burnout degrees also vary by specialty. Thus, among the 29 medical specialties surveyed, urologists (54\%), neurologists (53\%) and physicians dealing in physiotherapy and rehabilitation (52\%) suffer the most from professional burnout. A fairly large group of specialties with a high risk of occupational burnout (over $40 \%$ of respondents) could also be attributed to: therapy (49\%), emergency medical care (48\%), family medicine $(48 \%)$, diabetic and endocrine diseases (47\%), infectious diseases (46\%), general surgery (46\%), gastroenterology (45\%), obstetrics and gynecology (45\%), radiology (45\%), intensive care (44\%), cardiology (43\%), anesthesiology (42 $\%)$, rheumatology (41\%) and pediatrics (41\%). Physicians who specialize in public health and preventive medicine (28\%), nephrology (32\%) and pathological anatomy (33\%) experienced the least burnout (Physician burnout in 2019, 2019).

According to the 2018 survey, the specialties with the highest degrees of occupational burnout were: intensive care $(48 \%$ of respondents), neurology (48\%), family medicine (47\%), obstetrics and gynecology (46\%) and therapy (46\%). The lowest degrees of occupational burnout specialties are plastic surgery (23\%), dermatology (32\%) and pathological anatomy (32\%) (Peckham, 2018).
When asked about the biggest factors for burnout, $59 \%$ of respondents said they had to deal with too much bureaucratic work (inserting clinical records, paperwork), and 34\% mentioned that they spent too much time at work. Other influential factors include: increasing computerization of medical facilities (electronic medical records) (32\%), lack of respect by the management of the institution/staff, colleagues or technical staff (30\%), inadequate pay/cost reimbursement (29\%), lack of control/autonomy (23\%), government regulation (20\%), feeling like a cog in a big mechanism (20\%), emphasis on profit, not on patients (17\%), lack of respect from patients (16\%) (Physician burnout in 2019, 2019). The report provides physicians' statements about the causes of their professional burnout. One endocrinologist surveyed, for example, believes that "because of the incompetence of third-party organizations in collecting data, we have to do a lot of extra work", a family physician complains that "paperwork spoils all the fun of the physician's profession" and one dermatologist complains that "Everything is exacerbated by fear of prosecutions, bad reviews, and complaints" (Kane, 2019).

When asked how they cope with burning sensation, $48 \%$ of physicians said they were exercising, while $43 \%$ said they were talking to family members or close friends. Quite a few respondents $(41 \%)$ said that they find a way out in self-isolation. Sleeping and playing musical instruments or listening to music save $39 \%$ and $33 \%$ of physicians, respectively, from burnout. About a third of respondents (32\%) said they were eating junk food, while just over a fifth (23\%) said they consumed alcohol. The least respondents were comforted by smoking cigarettes or consuming nicotinecontaining products (3\%), prescription drugs (2\%) and smoking marijuana or products containing it (1\%) (Kane, 2019). So it can be stated that in the fight against the feeling of professional burnout American physicians use both positive life skills and not entirely adequate methods that, although alleviating the 
symptoms, do not solve the problem as such.

Just under two-thirds of physicians (62\%) mentioned that they did not plan to seek professional assistance with their feelings of burnout or depression (and had not done that in the past), $13 \%$ had previously received professional assistance, $12 \%$ of respondents were searching for appropriate ones at the time of the survey professionals and only $3 \%$ planned to do so. Therefore, the vast majority of physicians do not seek assistance in case of burnout or depression (Kane, 2019). "Medical training teaches us that we need to put up with this, so seeking assistance is not a well-established skill among physicians", said P. Wible, who is a medical physician and chief spokesman for the fight against physician suicide. "Due to the fact that most physicians are overworked, exhausted and dissatisfied, they have normalized their plight and pretend that not everything is as bad as it seems" (Wible, 2017).

When asked about the reasons for not seeking professional assistance, $50 \%$ of respondents stated that their symptoms were not sufficiently pronounced, $47 \%$ said they could fight their burnout without professional assistance, 39\% cited their over-employment, and $7 \%$ said they did not trust mental health professionals. As one nephrologist surveyed said, "The problem is not in me, yet the medical system itself is the only one that needs assistance" (Kane, 2019).

During the survey, physicians were also asked about their job satisfaction. As with burnout, overall job satisfaction depends on the specific specialty. So, the most satisfied with their work are plastic surgeons (41\%), followed by physicians working in public health and preventive medicine (40\%), ophthalmologists (39\%) and dermatologists (34\%). At the same time, physicians with the following specialties are the least satisfied with their work: therapy (21\%), emergency medical care (21\%), physiotherapy and rehabilitation (19\%). The share of family physicians who are satisfied with their work is only $23 \%$. Therefore, many physicians are generally satisfied with their work. However, it is noteworthy that the three groups of respondents who are most satisfied with their work dermatologists, pediatricians, and physicians working in public health and preventive medicine - are also among those who work the least overtime (Kane, 2019).

The American Academy of Family Physicians (AAFP) is concerned about the high degree of occupational burnout among physicians in the United States. For instance, a Medscape poll in 2017 showed that burnout degrees for all medical respondents have been increasing since 2013 (this year physicians first asked about burnout), where overall degree was 40\%. According to the 2017 survey, this number was already at $51 \%$, i.e. it had increased by $25 \%$ in four years (Peckham, 2017). A large survey in 2015 also confirmed these findings, reporting that burnout and physician satisfaction with work-life balance worsened between 2011 and 2014. More than half of physicians reported burnout (Shanafelt et al., 2015).

The problem of occupational burnout is important for AAFP, as family physicians suffer from significantly higher burnout degrees than most other specialties (Shanafel et al., 2016). In Medscape Lifestyle 2017: Race and Ethnicity, Prejudice and Burnout, 2017 (Medscape Lifestyle Report, 2017), the highest percentage of burnout was reported by emergency physicians (59\%) there are obstetricians/gynecologists (56\%), followed by family physicians, therapists and infectious diseases physicians (55\% each). It is easy to see that the top four included physicians who work directly with patients and therefore face a number of complex problems. Medscape Physician Lifestyle Report 2015 and 2016 Medscape Lifestyle Report 2016 included the top five occupational burnout specialties, including emergency physicians, family physicians and therapists (Peckham, 2017). Not surprisingly, other studies, such as in Israel and Australia, have found high burnout degrees in these three occupations (Ben-Itzhak et al., 2015; Arora et al., 2013). Burnout can adversely affect the quality of patient care and lead to physician 
discontinuation, thereby contributing to labor shortages in primary care (Shanafelt et al., 2016).

The importance of identifying and eliminating the root causes of a physician's burnout cannot be overstated. Despite many studies, there is still no definitive data on the causes of burnout (Gabbard, 2013). Studies show that common causes of burnout for family physicians include: paperwork, feelings of underestimation, frustration with online referral systems, complex patients, forensic issues, worklife balance issues (Lee, Stewart and Brown, 2008; Dyrbye, Varkey, Boone, et al., 2013). These factors have different effects at different stages of a physician's career. The inability to resolve the conflict between work and personal life, personhood and frustration in choosing a profession are the factors that have the greatest impact in the beginning of a physician's career (up to 10 years), whereas in the middle (11-20 years) - long working hours' day, frequent night calls, frustration with the administrative burden, dissatisfaction with the chosen specialty, and pay issues (Dyrbye et al., 2013).

In 2013, the American Medical Association (AMA) commissioned Rand corporations to identify the primary determinants of physician professional satisfaction. Using blended research methods (first and foremost qualitative), the project contractors sought to identify a wide range of potential targets for the development of special measures to increase physician satisfaction. The study found that two important factors affecting the level of professional satisfaction are the use of electronic health records (EHRs) and physicians' perceptions of their ability to provide high-quality care (Friedberg et al., 2013). Other factors affecting the professional satisfaction of the physician include autonomy and self-control, practical leadership, collegiality, fairness and respect, volume and pace of work, regulatory and professional liability issues, job content, allied health professionals and support staff (Friedberg et al, 2013).
AAFP believes that the level of understanding of how physician burnout directly affects a patient's health continues to increase (Family Physician Burnout, 2017). Studies show that the symptoms of burnout may be associated with an increase in the incidence of medication errors, riskier prescribing, and worse implementation of chronic disease treatment plans by patients. Surveys conducted in their time indicate that $50 \%$ of physicians and $70 \%$ of the US population consider overtime, stress, and overwork as a contributing factor to medical errors (Shanafelt et al., 2010, p. 995). As noted above, physicians who have reached the middle of their careers are more vulnerable to burnout for a number of reasons and feel more dissatisfied with work than physicians at other stages of their careers; Career practitioners are also more likely to leave clinical practice (Dyrbye et al., 2013). This is of particular concern to the AMA and AAFP, as the midcareer of a physician is usually the most productive step in assisting patients, fulfilling managerial and supervisory roles, and assuming important administrative roles. The fact that professional burnout causes some mid-career physicians to terminate clinical practice early may explain why job satisfaction is highest among older physicians who have already passed mid-career.

The AAFP program paper, "The Burnout, Wellbeing and Professional Satisfaction of a Family Physician", outlines the vision of the so-called Family Physician Burnout Ecosystem (2017). With a decent approach to this approach, each family physician uniquely feels his or her professional role in the context of many variables. These interacting variables form the ecosystem of the family physician. Against this background, potential solutions to improve personal well-being and professional satisfaction should be individualized based on the family physician's experience with this ecosystem.

In the AAFP vision, the family physician ecosystem in the US consists of five influential 
elements, in descending order from highest to lowest (baseline) (Fig. 1) (Family physician Burnout, 2017):

1. The level of the American health care system is the highest. This system is strictly regulated and mainly based on the principle of payment for medical services provided. Reporting and documentation requirements are a significant burden for family physicians, but they do not result in a proportionate improvement in the quality of care.

2. Organizational level. The vast majority of family physicians report that they either work full-time (88\%, at least 35 hours a week) or are part of organized medical staff (11\%), i.e., work part-time (American Academy of Family physicians, 2016). The values, requirements, and principles of the organization's activities can affect professional satisfaction.

3 . The level of practice. Features, characteristics, and effectiveness of the practice environment and the staff of the medical institution can affect the wellbeing and state of health of the family physician.

4. Individual-level. Individual health and wellbeing habits and life-sustaining potential can influence a family physician's response to external stressors.

5. The level of physician culture is basic. A culture that encourages self-sacrifice or even neglect in service to others can contribute to a sense of shame and guilt when a family physician is unable to reach superhuman levels of performance. Support from colleagues at this level is often unavailable.

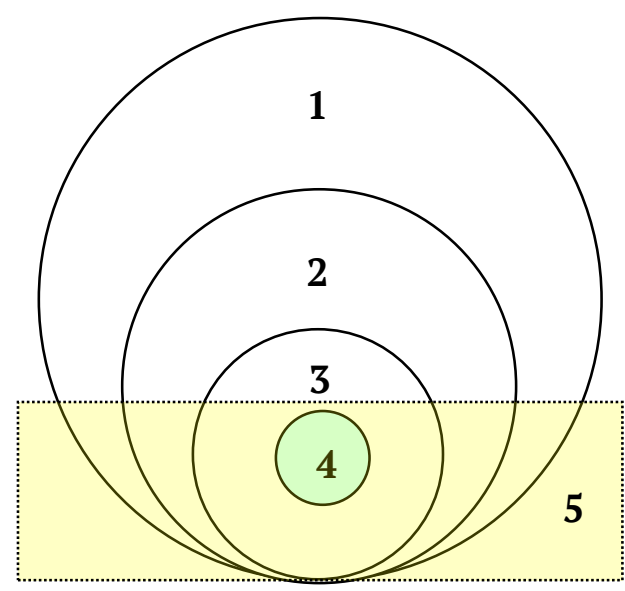

Levels:

1. Health care system.

2. Organization.

3. Practice.

4. Individual.

5. Doctor's culture.

Fig. 1. Family physician Ecosystem in the United States

Source: Adapted from (Family physician Burnout, 2017).

The AAFP emphasizes that the American health care system needs physicians to make the transition to new methods of care and to participate effectively in it. However, the fact that more than half of American physicians' experience burnout symptoms may compromise their ability to be effective in promoting and supporting the changes needed (Shanafelt et al. 2010). Against this background, reducing the level of burnout for physicians is a critical task for achieving the goals of reforming the health care system and improving the health of patients, families, and communities in the United States (Family physician Burnout, 2017).
The need to understand the factors and drivers of physician burnout stimulates the development of practical intervention models to prevent burnout and leads to the establishment of support services to help physicians cope with symptoms. Historically, most burnout programs have focused on the treatment of individual physicians (e.g., counseling services) (Family physician Burnout, 2017). However, studies have found that training self-awareness and mindfulness can reduce a physician's burnout and improve both his/her wellbeing and patient-centered qualities (Krasner et al., 2009, p. 1290). AAFP notes that health systems and other physicians' employers tend to 
use more system-wide measures, such as the introduction of institutional success criteria, including indicators of physician satisfaction and wellbeing, and the development of best practice models physician decision-making autonomy (Family physician Burnout, 2017). Given the increasing incidence of occupational burnout, physicians recommend that organizations urgently develop individual and systemic approaches to reduce the risk of burnout (Dunn et al, 2007).

In the United States today, organizations often seek to reduce burnout through activities that directly target the physician: forming supporting groups or peer forums, providing psychiatric assistance to physicians, training, and coaching. Noting the importance of these steps to reduce the workload and professional burnout of physicians, experts, however, note that when it comes to eradicating burnout as a phenomenon and preventing it in the future, another approach should be chosen (Kuzmanovich, 2018). In their recommendations, they draw on the results of a thorough study (Panagioti et al., 2017), dedicated to analyzing the effectiveness of interventions aimed at reducing burnout, when team of scientists evaluated the effectiveness of two types of burnout interventions, namely, direct-tophysician, i.e. personal orientation, and organization, hence, focused on improving the workplace environment. Based on a metaanalysis of 20 controlled activities involving 1 550 physicians, the researchers concluded that the existing activities were associated with small benefits that could be enhanced by adopting organizational approaches as compelling evidence of effectiveness was identified precisely in such activities, although there were quite a few (Panagioti et al., 2017). This conclusion supports the point of view that burnout is a problem for the entire healthcare organization, not for individuals. In the long run, physician-centered approaches are likely to be insufficient if the causes of burnout stem from factors of the organization or health system in general (Kuzmanovich, 2018).
In the context of the above, the US Advisory Board Company that specializes in the study and dissemination of health care excellence, consultancy, and new technologies, has identified four strategies that can help health care leaders weaken key factors professional burnout (Advisory Board Company, 2017):

1. Begin with a campaign to listen to your physician carefully. Create safe places for physicians to report (face-to-face and in groups) about their experiences and problems that contribute to burnout.

2. Strive for a balance of feedback and account of service merit. Neutralize the negative factors for physicians by spreading positive feedback and using comments from trusted sources such as patient satisfaction surveys.

3. Give physicians an active role in decision making. If necessary, give physicians a choice as to how new initiatives will affect their daily practices and work-life balance.

4. End the practice of withholding problems by emotional support. Allow physicians to learn effective communication strategies, discuss disorders, breakdowns, and frustrations, and discuss tactical steps for personal healing.

\section{Conclusions.}

Summarizing the results of the research, one can make the following conclusions:

1. The professional burnout of physicians has been a matter of concern for the government, professional medical associations, and the general public for physicians of various US specialties for a long time. With this in mind, professional burnout studies of physicians also have a long-standing history, and there is currently considerable scientific excellence in the United States. The first scientific publications on burnout at work appeared in the United States in the mid-1970s and went from exploring the phenomenon of burnout as such, then, in the 1980 s, to the stage of systematic quantitative empirical research based on the use of questionnaires and survey methodologies, and finally, in the 1990s, they were further 
developed, expanding into new professional fields and using more sophisticated methodology and improved statistical tools. All those allowed scientists to investigate the contribution to the burnout process of many potential impacts and consequences at the same time, as well as evaluate the effectiveness of specific measures designed to reduce burnout. Also, the problem of burnout is widely covered in the media.

2. Although burnout affects physicians of all disciplines, it is above average for family physicians, especially compared to the general economically active US population. At the same time, studies have found a decline in family physicians' satisfaction with work-life balance. AAFP believes that physician burnout is an important issue that needs to be addressed openly and actively as it adversely affects both patient safety and the wellbeing of the physician. Besides, burnout often leads family physicians to decide to leave clinical practice, especially in the middle of their careers, which affects patients' access to quality care. Burnout also affects the ability of family physicians to make positive changes at the level of their practices and the health care system as a whole.

3. There are currently two approaches to identifying, reducing risk, and/or eradicating the professional burnout of physicians in the American scientific literature. The first approach involves directly targeting a physician, i.e., a specific individual, such as mindfulness or cognitive-behavioral therapy to improve coping and communication skills, increase competence. The second approach involves measures aimed at the organization, that is when the focus is on the condition of the physician's work environment. Such measures relate to changes in the physician's work schedule and workload, clinical practice, and decision-making processes at the medical facility. American scientists have come to the conclusion that measures aimed at the organization are more effective, but the first approach should be used as a first step in overcoming professional burnout.

4. Based on regular sociological surveys, the results of numerous scientific papers and opinions of the AMA and AAFP experts strongly believe that burnout is a problem for the health care system, organization of the medical institution, clinical practice and personal culture of the physician, not only the issue of "individual concern" or mental vulnerability. With this in mind, in order to properly identify and eradicate the root causes of professional burnout at all levels of the family physician ecosystem (from the health system to the individual physician culture), AAFP applies an organization-oriented approach, that is, a health care facility and a national health care system.

\section{References}

Advisory Board Company (2017), “4 key strategies to mitigate physician burnout”, available at https://www.researchgate.net/publication/5951988 Meeting the Imperative to Improve Physician Well-being Assessment of an Innovative Program (Accessed 14 March 2019).

American Academy of Family Physicians (2016), AAFP Member Census, December 31, 2016. Table 4: Selected practice characteristics of active AAFP members, available at https://www.aafp.org/about/the-aafp/familymedicine-specialty/facts/table-4.html (Accessed 13 March 2019)

American Academy of Family Physicians (AAFP), available at https://www.aafp.org/home.html (Accessed 13 March 2019).

American Medical Association (AMA), available at: https://www.ama-assn.org/ (Accessed 13 March 2019).

Arora, M., Asha, S., Chinnappa, J., Diwan, A. D. (2013), "Review article: burnout in emergency medicine physicians", Emergency medicine Australasia: EMA, vol. 25, no. 6, pp. 491-495, doi: https://doi.org/10.1111/1742-6723.12135

Ben-Itzhak, S., Dvash, J., Maor, M., Rosenberg, N., Halpern, P. (2015), "Sense of meaning as a predictor of burnout in emergency physicians in Israel: a national survey", Clinical and Experimental Emergency Medicine, vol. 2, no. 4, pp. 217-225, doi: https://doi.org/10.15441/ceem.15.074

Chan, A.O. et al. (2015), "Addressing physician quality of life: understanding the relationship between burnout, work engagement, compassion fatigue and satisfaction”, Journal of Hospital Administration, 4(6), pp. 46- 
55, doi: http://dx.doi.org/10.5430/iha.v4n6p46.

Dunn, P. M., Arnetz B. B., Christensen, J. F., Homer, L. (2007), "Meeting the imperative to improve physician well-being: assessment of an innovative program", Journal of General Internal Medicine, vol. 22, no. 11, pp. 1544-1552, doi: https://doi.org/10.1007/s11606-007-0363-5

Dyrbye, L. N, Varkey, P., Boone, S. L., Satele, D. V., Sloan, J. A., Shanafelt, T. D. (2013), "Physician satisfaction and burnout at different career stages", Mayo Clinic Proceedings, vol. 88, no. 12, pp. 1358-1367, doi: https://doi.org/10.1016/i.mayocp.2013.07.016

Family Physician Burnout, Well-Being, and Professional Satisfaction (Position Paper) (2017), available at https://www.aafp.org/about/policies/all/physician-burnout.html (Accessed 13 March 2019).

Freudenberger, H. J. (1974), “The Staff Burnout Syndrome in Alternative Institutions”, Psychotherapy: Theory, Research and Practice, vol. 12, no. 1, pp. 73-82, doi: http://dx.doi.org/10.1037/h0086411

Friedberg, M. W., Chen, P. G., Van Busum, K. R., et al. (2013), Factors affecting physician professional satisfaction and their implications for patient care, health systems, and health policy, Rand Health, Santa Monica, CA, 150 p., available at: https://www.rand.org/content/dam/rand/pubs/research reports/RR400/RR439/RAND RR439.pdf (Accessed 12 March 2019).

Gabbard, G. O. (2013), “Medicine and its discontents”, Mayo Clinic Proceedings, vol. 88, no. 12, pp. 1347-1349, DOI: https://doi.org/10.1016/j.mayocp.2013.10.007

Health at a Glance: Europe 2018. State of health in the EU cycle (2019), available at https://ec.europa.eu/health/sites/health/files/state/docs/2018 healthatglance rep en.pdf (Accessed 21 March 2019).

Hromtseva, D. and Krupskyi, O. (2015), "Professional culture and security: an innovative approach to implementing a medical facility”, European Journal of Management Issues, no. 23(5), pp. 15-23, doi: http://dx.doi.org/10.15421/191517.

Kane, L. (2019), “Medscape National Physician Burnout, Depression \& Suicide Report 2019”, available at: https://www.medscape.com/slideshow/2019-lifestyle-burnout-depression-6011056?faf=1\#1 (Accessed 10 March 2019).

Krasner, M.S., Epstein, R. M., Beckman, H., et al. (2009), “Association of an educational program in mindful communication with burnout, empathy, and attitudes among primary care physicians”, JAMA, vol. 302, no. 12 , pp. 1284-1293, doi: 10.1001/jama.2009.1384

Kuzmanovich, D. (2016), "Listening: The prescription for the physician burnout epidemic", available at https://www.advisory.com/research/medical-group-strategy-council/practice-notes/2016/10/physician-

burnout-listening (Accessed 14 March 2019).

Kuzmanovich, D. (2018), "What burnout interventions work best? Here's what the data says", available at https://www.advisory.com/research/medical-group-strategy-council/practice-notes/2017/02/doctors-burnout (Accessed 14 March 2019).

Lee, F. J, Stewart, M., Brown, J. B. (2008), “Stress, burnout, and strategies for reducing them: what's the situation among Canadian family physicians?”, Canadian family physician, vol. 54, no. 2, pp. 234-235, available at https://www.researchgate.net/publication/5578761 Stress burnout and strategies for reducing them What's the situation among Canadian family physicians (Accessed 12 March 2019).

Liu, J. (2016), "The changing physician workforce", available at https://www.advisory.com/research/health-careindustry-committee/members/multimedia/infographics/the-changing-physician-workforce?WT.ac=GrayBox HCIC Info PN 20160ct13 (Accessed 14 March 2019).

Martin, L. (2016), “Three surprising truths about physician burnout Expert Perspective”, available at https://www.sgo.org/wp-content/uploads/2016/07/Three-surprising-truths-about-physician-burnout-TheAdvisory-Board-Company.pdf (Accessed 14 March 2019).

Maslach, C. (1976), “Burned-Out”, Human Behavior, vol. 5, no. 9, pp. 16-22.

Maslach C, Schaufeli W. B. and Leiter M. P. (2001), “Job burnout”, Annual Review Psychology, vol. 52, pp. 397422, doi: https://doi.org/10.1146/annurev.psych.52.1.397

Maslach, C. and Leiter, M.P. (2016), "Burnout”, Stress: Concepts, Cognition, Emotion, and Behavior, pp. 351357, doi: http://dx.doi.org/10.1016/b978-0-12-800951-2.00044-3.

Maslach, C., Jackson S. E. (1981), “The measurement of experienced burnout”, Journal of Organizational Behavior, vol. 2, no. 2, pp. 99-113, doi: https://doi.org/10.1002/job.4030020205

McManus, I., Winder, B. and Gordon, D. (2002), “The causal links between stress and burnout in a longitudinal study of UK doctors”, The Lancet, no. 359(9323), pp. 2089-2090, doi: http://dx.doi.org/10.1016/s01406736(02)08915-8.

Medscape Lifestyle Report 2016: Bias and Burnout (2016), available at https://www.medscape.com/slideshow/lifestyle-2016-overview-6007335\#page=2 (Accessed 12 March 2019). 
Medscape Lifestyle Report 2017: Race and Ethnicity, Bias and Burnout (2017), available at https://www.medscape.com/features/slideshow/lifestyle/2017/overview\#page=1 (Accessed March 12, 2019).

Medscape Physician Lifestyle Report 2015 (2015), available at https://www.medscape.com/sites/public/lifestyle/2015 (Accessed 12 March 2019).

Montgomery, A. et al. (2013), "Improving quality and safety in the hospital: The link between organizational culture, burnout, and quality of care", British Journal of Health Psychology, vol. 18, no. 3, pp. 656-662, doi: http://dx.doi.org/10.1111/bjhp.12045.

Myhren, H., Ekeberg, Ø. and Stokland, O. (2013), "Job Satisfaction and Burnout among Intensive Care Unit Nurses and Physicians", Critical Care Research and Practice, 2013, pp. 1-6, doi: http://dx.doi.org/10.1155/2013/786176.

Nahrgang, J. D., Morgeson, F. P. and Hofmann, D. A. (2011), "Safety at work: A meta-analytic investigation of the link between job demands, job resources, burnout, engagement, and safety outcomes", Journal of Applied Psychology, vol. 96, no. 1, pp. 71-94, doi: http://dx.doi.org/10.1037/a0021484.

Panagioti, M., Panagopoulou, E., Bower, P. et al. (2017), "Controlled Interventions to Reduce Burnout in Physicians. A Systematic Review and Meta-analysis”, JAMA Internal Medicine, vol. 177, no. 2, pp. 195-205, doi: https://doi.org/10.1001/jamainternmed.2016.7674

Peckham, C. (2017), “Medscape Lifestyle Report 2017: Race and Ethnicity, Bias and Burnout", available at https://www.medscape.com/features/slideshow/lifestyle/2017/overview\#page=2 (Accessed 12 March 2019).

Peckham, C. (2018), "Medscape National Physician Burnout and Depression Report 2018”, available at https://www.medscape.com/slideshow/2018-lifestyle-burnout-depression-6009235 (Accessed 10 March 2019).

Physician burnout in 2019, charted (2019), available at https://www.advisory.com/daily-briefing/2019/01/18/burnout-report (Accessed 10 March 2019).

Shanafelt, T. D., Balch, C. M., Bechamps, G., et al. (2010), "Burnout and medical errors among American surgeons”, Annals of Surgery, vol. 251, no. 6, pp. 995-1000, doi: https://doi.org/10.1097/sla.0b013e3181bfdab3

Shanafelt, T. D., Dyrbye, L. N., Sinsky, C., Hasan, O., Satele, D., Sloan, J. and West, C. P. (2016), "Relationship Between Clerical Burden and Characteristics of the Electronic Environment With Physician Burnout and Professional Satisfaction", Mayo Clinic Proceedings, vol. 91, no. 7, pp. 836-88, doi: https://doi.org/10.1016/i.mayocp.2016.05.007

Shanafelt, T. D., Hasan, O, Dyrbye, L. N., Sinsky, C., Satele, D., Sloan, J. and West, C. P. (2015), "Changes in burnout and satisfaction with work-life balance in physicians and the general US working population between 2011 and 2014", Mayo Clinic Proceedings, vol. 90, no. 12, pp. 1600-1613, doi: https://doi.org/10.1016/j.mayocp.2015.08.023.

Tools and methodologies to assess the efficiency of health care services in Europe. An overview of current approaches and opportunities for improvement: Report by the Expert Group on Health System Performance Assessment (2019), available at https://ec.europa.eu/health/sites/health/files/systems performance assessment/docs/2019 efficiency en.pdf (Accessed 21 March 2019).

Webb, L. E. et al. (2016), "Using Coworker Observations to Promote Accountability for Disrespectful and Unsafe Behaviors by Physicians and Advanced Practice Professionals”, The Joint Commission Journal on Quality and Patient Safety, vol.42, no. 4, pp. 149-161, AP1-AP3, doi: http://dx.doi.org/10.1016/s15537250(16)42019-2.

Weng, H.-C. et al. (2011), "Associations between emotional intelligence and doctor burnout, job satisfaction and patient satisfaction”, Medical Education, vol. 45, no. 8, pp. 835-842, doi: http://dx.doi.org/10.1111/i.13652923.2011.03985.x.

Wible, P. (2017), "Doctors and Depression: Suffering in Silence”, available at https://www.medscape.com/viewarticle/879379 2 (Accessed 11 March 2019).

Wible, P. (2018), "Two Powerful Ways to Help End the Physician Suicide Epidemic", available at https://www.medscape.com/viewarticle/904114 (Accessed 12 March 2019).

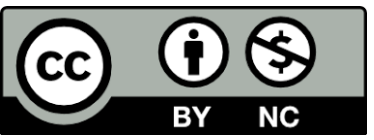

Цей твір ліцензовано на умовах Ліцензії Creative Commons «/з Зазначенням Авторства - Некомерційна 4.0 Міжнародна» (CC BY-NC 4.0). This is an open access journal and all published articles are licensed under a Creative Commons "Attribution-NonCommercial 4.0 International" (CC BY-NC 4.0). 